\title{
Accounting
}

\section{Simultaneous adjustment of bank capital and risk: Evidence from the Indonesian commercial banks}

\author{
Lutfi Lutfi ${ }^{a}$, Emanuel Kristijadia and Mellyza Silvy ${ }^{a}$
}

\begin{tabular}{l}
${ }^{a}$ Department of Management, STIE \\
\hline C H R O N I C L E \\
\hline Article history: \\
Received May 152020 \\
Received in revised format May \\
162020 \\
Accepted June 292020 \\
Available online \\
June 30 2020 \\
\hline Keywords: \\
Capital adjustment \\
Risk adjustment \\
Simultaneous model \\
Indonesian bank
\end{tabular}

\section{Introduction}

Capital plays an important role in absorbing bank losses (Rime, 2001), ensuring that banks are able to pay obligations and support growth (Porteous \& Tapadar, 2005). Banks with large capital have more funds for business expansion, including credit expansion which is riskier compared to other placements of funds, such as Government Bonds. Banks must be able to determine appropriately the amount of capital needed to absorb the unexpected losses (Rowe et al., 2004). The failure of banks to provide adequate capital could cause banks to be unable to cover large losses and the worst is a systemic liquidity crisis. For example, in order to restore national banking as a result of the systemic crisis in the late 1990s, the Indonesian Government had to provide bailouts through the issuance of recapitalization bonds worth Rp.430 trillion (Hadad et al., 2003). One of crucial decisions made by banks is to deal with capital and risk and this decision must be made at the same time (Jacques \& Nigro, 1997; Shrieves \& Dahl, 1992). This means that the level of risk that the bank will take in a period is more determined by the amount of capital held by the bank in that period, not by the amount of capital in the previous period. Jacques and Nigro (1997), Shrieves and Dahl (1992) state there is a positive reciprocal influence between changes in capital and changes in risk. Empirical evidence,

* Corresponding author.

E-mail address: lutfi@perbanas.ac.id (L. Lutfi) 
however, does not always show a positive relationship, as reflected in the views of two main theories about the relationship between changes in capital and changes in risk, namely portfolio theory and moral hazard theory. Kim and Santomero (1988) and Koehn and Santomero (1980) argue that capital increases can have unexpected effects that could cause banks to maximize utility to increase credit portfolio risk (Cannata \& Quagliariello, 2006; Godlewski, 2005; Jeitschko \& Jeung, 2007; Jokipii \& Milne, 2011; Van Roy, 2008). A different view of the relationship between capital levels and credit risk can be explained by moral hazard theory. Holmstrom and Tirole (1997) state that in a moral hazard theory framework banks would exploit depositors due to the information asymmetry. This moral hazard behavior is exacerbated by the existence of a deposit guarantee system. Banks have an incentive to reduce capital and increase the risk of assets because the deposit insurance institution guarantees the risk of loss, but the bank owner benefits when the bank makes a profit. This result in a negative relationship between changes in capital and changes in risk (Duran \& Lozano-Vivas, 2015; Ha, 2020; Nachane \& Ghosh, 2001; Siddika \& Haron, 2019).

The results of previous studies related to the reciprocal influence between changes in capital and risk, as explained above, are indecisive. Differences in results could be caused by moderating variables that have a contingency effect on the relationship between changes in bank capital and changes in credit risk. The first moderating factor that could moderate the relationship between changes in risk and changes in capital is capital buffer (Marcus, 1984). Banks with high capital buffers tries to maintain the soundness of the bank by increasing capital when increasing the risk, while banks with low capital or approaching the minimum capital requirement will increase their capital and at the same time reduce the risk to avoid violations of the minimum capital requirement (Diamond \& Rajan, 2000). The second factor that may moderate the relationship between capital and bank risk can be found in the business cycles theory of capital and risk adjustments (Borio et al., 2001). When the business cycle goes up, banks do not need to worry about deteriorating the performance of its credit portfolio so that they expand credit by loosening their credit policies without coupling with adequate capital formation (Asea \& Blomberg, 1998). When the economic cycle deteriorates, however, bank capital cannot absorb the increased credit risk and therefore forcing the bank to increase its capital (Stolz \& Wedow, 2011) and reduce lending (Quagliariello, 2007). So far there has been no published research in Indonesia that studies the effect of changes in capital on changes in risk and changes in risk to changes in capital simultaneously. Therefore, this study examines the mutual effects of changes in credit risk and changes in capital of commercial banks in Indonesia based on a simultaneous approach. In addition, researches that specifically examines the effect of capital buffer is still very limited in emerging economies. The availability of this capital buffer will influence the bank's behavior in taking credit risk and capital adjustment, in the sense that banks with high capital buffer (large excess capital) will have different risk and capital adjustment behaviors with banks that have low capital buffer or whose capital is close minimum provisions. The second objective of this study is to examine the moderating role of capital buffer in the influence of changes in capital to changes in credit risk and changes in credit risk to changes in bank capital in Indonesia by using a simultaneous approach. Finally, the explanations described earlier show that the business cycle affects the level of credit risk taken by banks and the formation of bank capital. Empirical evidence about the effect of the business cycle on capital adjustment and risk is still very limited and all is done in developed countries where the economy and banking system are relatively stable. The third objective of this study, therefore, is to examine the role of the business cycle in moderating the effect of capital changes on changes in credit risk and changes in credit risk to changes in capital.

\section{Theoretical Framework and Hypothesis Development}

\subsection{Adjustments in Bank Capital and Risk}

A number of empirical studies have analyzed the interplay between credit risk and capital. Shrieves and Dahl (1992) analyze the relationship between changes in capital and changes in portfolio risk of banks in America. and find a positive reciprocal influence between capital and bank risk taking. Ediz et al. (1998) use data of UK and show that the requirement to provide capital encourages banks to increase their capital ratios. The UK banks adjust their capital ratio primarily by directly increasing capital, not by systematically transferring from high-risk assets to low-risk or risk-free assets, such as Government. Rime (2001) examines the impact of capital regulation on banks in Switzerland finds that Swiss banks whose capital is close to the minimum capital requirement are likely to adjust the capital ratio to risk-weighted assets. Regulatory pressures in the form of an increase in the minimum capital ratio have a positive and significant impact on bank risk taking, which means that an increase in capital encourages banks to increase their risk. Nachane and Ghosh (2001) examine the impact of changes in riskbased capital ratios in India and show that there is a significant negative effect of changes in risk on changes in capital and a positive effect on changes in capital to risk changes. Cannata and Quagliariello (2006) use bank data in Italy and shows that risk changes positively affect changes in capital in the same period, while changes in capital negatively affect changes in risk. Godlewski (2005) uses a sample of banks from developing countries from Eastern Europe, Asia and South America and find that changes in capital have a positive effect on changes in risk, but no significant evidence on the influence of changes in credit risk to changes in capital. Siddika and Haron (2019) use a sample of banks from 52 countries and find that the increase in bank capital ratio lead to a decrease in bank risk. Ha (2020) uses data of 35 Vietnamese banks and shows the bank equity level positively affects bank risk. Raz (2018) studies the relationship between risk and capital of fifteen large banks in Indonesia and 
shows that capital has a negative impact on risk. Based on the study of the relationship between capital and bank credit risk above, two conclusions can be drawn. First, the majority of researchers agree that there is a positive influence of capital on risk, namely the greater the capital, the greater the risk taken by the bank. This is in line with the mean-variance framework in the portfolio model (Kim \& Santomero, 1988; Koehn \& Santomero, 1980). Second, most studies conclude that bank risk taking has a positive effect on changes in capital, Therefore, this study hypothesizes that

H1: $\quad$ Changes in bank risk have a positive effect on changes in bank capital. $\mathrm{H} 2$ : $\quad$ Changes in bank capital have a positive effect on changes in bank risk.

\subsection{Bank Specific Factors Determining Capital and Risk Adjustments}

Shrieves and Dahl (1992), Jacques and Negro (1997) state that banks adjust the level of risk and capital levels in a given period simultaneously towards a targeted optimal risk and capital levels. This means that the bank must determine the optimal level of capital based on the level of optimal risk that it wants to take, where the optimal level of risk is influenced by various factors and one of the main factors is the level of capital itself. The implication is that banks must first estimate the optimal level of risk taken based on various factors that influence it and then use the results of these estimates to determine the level of capital. The first factor that is commonly the determinant of bank optimal capital is bank size, as measured by its total assets. The effect of the bank size on the capital ratio can be seen from many aspects. First, large banks tend to have better access to funding sources so that would need lower capital ratios compared to those of small banks (Cannata \& Quagliariello, 2006; Ghosh, 2014; Shim, 2013; Van Roy, 2008). Second, large banks tend to get more protection from the government because large bank failures can have a systemic impact (Beccalli et al., 2015; Jokipii \& Milne, 2011). Third, Basel II allows banks to choose between a standardized and internal rate based (IRB) approach. IRB implementation requires a large investment so that only big banks are able to implement it (Hakenes \& Schnabel, 2011). This more sophisticated risk-based capital calculation approach allows large banks to require more capital ratios than those required by smaller banks. Last, Large banks are more able to diversify their risk into various products so that they have lower risk and lower capital requirements than those needed by small banks (Altunbaş et al., 2001; Shim, 2013). Thus, banks with large assets tend to require lower capital reserves than banks with small assets because large banks are easier to get new funds when they need it and because of more protection from the government, so that bank assets negatively affect changes in capital. Another factor influencing a bank capital is its profitability. Profitability is the level of profit generated internally by the bank from the utilization of its assets. It is one of the main sources of bank core capital. Banks may prefer to increase capital from retained earnings rather than issuing new shares because the later alternative is costly (Shim, 2013)and could give a negative signal to the market (Cannata \& Quagliariello, 2006; Jokipii \& Milne, 2011). The higher the level of bank profitability, the greater the bank's ability to accumulate capital from internal sources. Previous research results show that profitability has a positive effect on bank capital ratios (Aggarwal \& Jacques, 1998; Altunbaş et al., 2001; Cannata \& Quagliariello, 2006; Ediz et al., 1998; Van Roy, 2008; Setyawati et al., 2019; Basheer et al., 2019). The ability of banks to absorb risk is also affected by the amount of liquid assets. Banks use liquid assets as a substitutes for capital to absorb bank risk (Jokipii \& Milne, 2011; Yu, 2000). The greater the liquid assets owned by the bank, the easier it is for banks to sell these assets to meet funding and liquidity needs so that less capital is needed (Wagner, 2007). High liquidity can also be a signal that the bank financial condition is sound so that the public, especially depositors, would be more confident in the bank. Thus, liquidity is expected to negatively affect changes in capital (Altunbaş et al., 2001; Jokipii \& Milne, 2011). The last variable affecting the capital adjustment is lag of the capital. The bank's decision to increase its capital is strongly influenced by the ratio of capital held in the previous period. The bank adjusts its capital towards the optimal capital ratio gradually over time (Aggarwal \& Jacques, 1998; Jacques \& Nigro, 1997; Shrieves \& Dahl, 1992). Banks that have a high capital relative to assets in the previous period could increase the risk of their asset portfolio without having to increase capital. This causes the capital to asset ratio to decline in the next period. Thus, lag of capital negatively affects changes in capital (Cannata \& Quagliariello, 2006; Godlewski, 2005; Nachane \& Ghosh, 2001; Rime, 2001; Van Roy, 2008). Based on the explanation above, this study hypothesizes

H3: $\quad$ Bank size has a negative effect on changes in bank capital.

H4: $\quad$ Bank profitability has a positive effect on changes in bank capital.

H5: $\quad$ Bank liquidity has a negative effect on changes in bank capital.

H6: $\quad$ Lags of capital have a negative effect on changes in bank capital.

As with capital, banks also adjust risk taken towards the optimal level of risk (Jacques \& Nigro, 1997; Shrieves \& Dahl, 1992). The optimal level of risk is influenced by the amount of capital reciprocally and other bank-specific factors (Jokipii \& Milne, 2011). The first bank specific factor influencing the risk taking is the bank size, as measured by the total assets. Large banks have more products to diversify their risks so they tend to have a lower risk profile compared to those of smaller banks (Altunbaş et al., 2001; Demsetz \& Strahan, 1997; Shim, 2013). Large banks have a competitive advantage over small banks in terms of sources of funding for credit distribution (Hakenes \& Schnabel, 2011). This forces small banks to take more risks in order to survive in increasingly fierce banking competition (Bhagat et al., 2015). Another factor influencing bank risk taking is 
profitability. There is a trade-off between the expected level of profit and the level of risk taken by the bank (Boyd \& De Nicolo, 2005). Banks must be willing to bear higher risk, by channeling more of their funds into credit, when targeting higher profit levels (García-Herrero et al., 2009; Tan et al., 2017). Fund placements in the form of credit offer a higher rate of return but also have the potential for higher defaults and therefore have a greater risk compared to placements in Government Securities. Jeitschko and Jeung (2007), Godlewski (2005) show a positive influence of profitability, as measured by return on assets (ROA), to the level of risk as measured by risk-weighted assets. The bank risk taking is also affected by allowance for loan losses. Allowance for loan losses the amount of allowance for assets classified as special attention, sub-standard, doubtful, and default. The allowance is positively related to previous year loan rate (Sinkey \& Greenawalt, 1991). The formation of allowance is an indication of the potential for high risk so banks need to take steps to reduce the risk of assets in the future (Rime, 2001; Van Roy, 2008). The last bank specific factor influencing risk taking is lag of risk. Banks with a high level of risk in the past, and without additional capital, will be forced to reduce the level of risk in the next period in order to maintain the level of capital adequacy. Conversely, banks that accumulate relatively low risk levels in the past are have better leeway in meeting capital availability so that they have more space to take greater risks. The results of empirical studies show that lag risk has a negative impact on bank risk taking in the future (Aggarwal \& Jacques, 1998; Cannata \& Quagliariello, 2006; Godlewski, 2005).

H7: $\quad$ Bank assets have a negative effect on changes in bank risk.

H8: $\quad$ Bank profitability has a positive effect on changes in bank risk.

H9: Allowance for loan losses has a negative effect on changes in bank risk.

H10: Lag of risk negatively affects changes in bank risk.

\subsection{The Moderating Role of Capital Buffer}

One of the moderating factors can be found in capital buffer theory, which is a dynamic version of the charter value (Marcus, 1984). Excess capital in the banking industry is intended to cover risks that have not been covered by minimum capital, the need for future expansion, and capital reserves to guard against bank capital not falling below the minimum requirements when there is a surge in risk. When capital falls below the minimum requirements, regulators can ask banks to immediately increase capital, temporarily suspend their activities or at the most extreme close bank activities. Banks that have low capital buffers are more likely to experience regulatory pressure so that they tend to increase their capital ratio faster compared to well-capitalized bank (Abbas \& Masood, 2020; Aggarwal \& Jacques, 1998; Altunbaş et al., 2001; Cannata \& Quagliariello, 2006; Van Roy, 2008). In terms of risk, banks that have low capital buffers tend to reduce risk more quickly than banks that have high capital when subjected to regulatory pressure. This is due to the non-fulfillment of minimum capital standards could cause banking regulators to cease their operations (Aggarwal \& Jacques, 1998; Jokipii \& Milne, 2011; Van Roy, 2008). Further evidence is provided by Heid et al. (2004) which states that banks with high capital buffer tend to raise capital and simultaneously increase risk proportionally in order to maintain the current capital buffer remains healthy, while banks that have low capital buffers tend to raise capital relatively higher than the risk to foster capital. Thus, it can be concluded that capital buffering weakens the influence of capital changes on credit risk and the effect of changes in credit risk on changes in capital.

H11: Bank capital buffer weakens the influence of changes in credit risk to changes in bank capital.

H12: Bank capital buffer weakens the effect of changes in capital to changes in bank risk.

\subsection{The Moderating Role of Business Cycle}

Another factor that can moderate the relationship between changes in capital and changes in bank credit risk is the business cycle (Borio et al., 2001). When the economy improves and experiences significant positive growth, banks need to increase their capital to support the increasing credit demand. Economic growth, however, can also have a negative impact on the bank's capital ratio, this is especially during a recession period where credit failures are very high. When credit risk is high, banks may shift their asset portfolio from credit to less risky assets, so that the bank risk weighted assets will decrease and the capital adequacy ratio will increase, even without additional capital. As long as credit risk fluctuates throughout the business cycle, the optimal capital buffer also fluctuates throughout the business cycle (Altman et al., 2005). Ayuso et al. (2004) find that capital buffering fluctuates in countercyclical directions throughout the cycle. The Bank enlarges its credit portfolio when the business cycle rises without being accompanied by capital formation. When the business cycle falls, bank capital cannot absorb credit risk that increases substantially so that the bank must increase its capital by reducing credit distribution. Marcucci and Quagliariello (2008) show that the business cycle has a negative effect on credit risk, as measured by the provision of nonperforming loans. Asea and Blomberg (1998) show that banks change their credit standards from strict to loose systematically during the business cycle. The pattern found shows that credit standard easing occurred during the expansion period (good economic conditions). On the other hand, García-Suaza et al. (2012) find that bank capital buffering varied during the business cycle, where there are opposing movements of capital and business cycles. They also find that large banks capital buffers exhibit counter-cyclical behavior, while small banks buffers tend to be constant over time. 
H14: Business cycle weakens the influence of changes in risk to changes in bank capital.

H13: Business cycle weakens the influence of capital changes to changes in bank risk.

\section{Research Methods}

The unit of analysis of this research is firm years. This study used a population of 96 national commercial banks for 13 years, from $2004-2018$. The 2004 data is used for calculating capital changes and credit risk changes, so that the research variable data is for 13 years, starting from 2005 - 2018. Based on the criteria described above, the sample of this study consists of 68 national commercial banks in Indonesia for 13 years, resulting in 884 observation. In order to make the data more homogeneous and to avoid undue influences from one or several observations, this study excludes outlier data, i.e. observations whose variable values lie outside the mean \pm 3 standard deviations (Hair et al., 2014). The dependent variables are change in capital and change in risk. Besides influencing by change in risk, change in capital is also affected by its lag, profitability, size, and liquidity. Likewise, changes in risk are influenced not only by capital changes but also by its lag, allowance for loan losses, profitability, and size. This study also includes two moderating variables, namely capital buffer and business cycle. Table 1 shows the research variables, the symbol, the measurement, and the data sources.

Table 1

Research Variable, Symbol, Measurement, Sources

\begin{tabular}{|c|c|c|c|}
\hline Variable Name & Symbol & Measurement & Source \\
\hline Capital Change & $\mathrm{d}(\mathrm{CAP})$ & CAP is the ratio of total Tier 1 capital to total assets. $d(C A P)=\mathrm{CAP}_{t}-\mathrm{CAP}_{\mathrm{t}-1}$ & \multirow{10}{*}{$\begin{array}{l}\text { Bank Indonesia } \\
\text { Financial Service Authority }\end{array}$} \\
\hline Risk Change & d(RISK) & $\begin{array}{l}\text { RISK is the ratio risk weighted asset to total assets } \\
d\left(\text { RISK) }=\text { RISK }_{t}-\text { RISK }_{t-1}\right.\end{array}$ & \\
\hline Lag of Capital & $\mathrm{CAP}_{\mathrm{t}-1}$ & $\mathrm{CAP}_{\mathrm{t}-1}$ is previous capital & \\
\hline Lag of Risk & RISKt $_{1-1}$ & RISK $_{t-1}$ is previous capital & \\
\hline Profitability & PROF & $\begin{array}{l}\text { PROF is measured using Return on Asset, that is equal to profit before taxes } \\
\text { divided by average total asset }\end{array}$ & \\
\hline Size & SIZE & SIZE is the $\log$ normal of total assets $=\mathrm{Ln}$ (Total Assets) & \\
\hline Liquidity & LIQ & $\begin{array}{l}\text { LIQ is the ratio of liquid assets consisting of cash, placement with central bank, } \\
\text { and securities issued by government or central bank, to total assets }\end{array}$ & \\
\hline $\begin{array}{l}\text { Allowance for } \\
\text { Loan Losses }\end{array}$ & ALL & ALL is the ratio of problem loans to total loans & \\
\hline Capital Buffer & BUF & $\begin{array}{l}\text { BUF is the amount of excess capital above the minimum capital requirement of } 8 \\
\text { percent }\end{array}$ & \\
\hline Business Cycle & $\mathrm{CYC}$ & $\begin{array}{l}\text { CYC is a dummy variable of the GDP growth rate. It is } 1 \text { if the growth rate at } \\
\text { time } t \text { is higher than the average, otherwise } 0 .\end{array}$ & \\
\hline
\end{tabular}

To test the hypothesis, this study uses panel data techniques, both fixed effect (FE) and Random Effect (RE). Panel data techniques could improve statistical analysis (Altunbaş et al., 2001). In order to optimize the utilization of statistics from the data, the panel data approach includes components of cross-sectional and time series influence (Gujarati \& Porter, 2009). The previous section has explained that bank decisions related to credit risk taking and capital adjustments are determined simultaneously. Shrieves and Dahl (1992), Jacques and Nigro (1997) state that banks face rigidity and adjustment costs that might prevent them from making discretionary adjustments immediately. But full adjustments may be too expensive and/or not feasible. Therefore, the bank adjusts the amount of risk and the capital is only partially towards the target level. The partial adjustment framework assumes that adjustments are proportional to the difference between the optimal and actual levels, as stated in Eq. (1) and Eq. (2).

$$
\begin{aligned}
& d C A P_{i, t}^{d}=\alpha\left(\text { CAP }_{i, t}^{*}-C A P_{i, t-1}\right)+\mu_{i, t} \\
& d R I S K_{i, t}^{d}=\beta\left(\operatorname{RISK}_{i, t}^{*}-\operatorname{RISK}_{i, t-1}\right)+v_{i, t}
\end{aligned}
$$

where $\alpha$ and $\beta$ are the speed of adjustment, $C A P_{i, t}^{*}$ and $R I S K_{i, t}^{*}$ and are the optimal target of capital and risk level, respectively, and $C A P_{i, t-1}$ and $R I S K_{i, t-1}$ are the actual level of capital and risk in the previous period (lag), respectively. The above equation underlines the fact that changes in the level of risk and capital in a period $t$ are a function of the difference between the risk and capital targets in period $t$ and in the previous period $(t-1)$ and exogenous surprises, $\mu_{i t}$ and $v_{i t}$, respectively. $\mu_{i t}$ and $v_{i t}$ consist of bank specific factors and white noise. To test the simultaneous relationship between capital and risk adjustment, this study uses Two-Stage Least Square (2-SLS). The complete empirical models of this study are as follow,

$$
\begin{aligned}
& d \operatorname{dAP}_{i, t}=\alpha_{0}+\alpha_{1} d R I S K_{i, t}+\alpha_{2} \operatorname{SIZE}_{i, t}+\alpha_{3} \text { PROF }_{i, t}+\alpha_{4} L I Q_{i, t}+\alpha_{5} C A P_{i, t-1}+\alpha_{6} B U F_{i, t} * d R I S K_{i, t}+\alpha_{6} C Y C_{i, t} * \\
& d R I S K_{i, t}+\mu_{i, t} \\
& d R I S K_{i, t}=\beta_{0}+\beta_{1} d C A P_{i, t}+\beta_{2} S I Z E_{i, t}+\beta_{3} P R O F_{i, t}+\beta_{4} A L L_{i, t}+\beta_{5} R I S K_{i, t-1}+\beta_{6} B U F_{i, t} * d C A P_{i, t}+\beta_{6} C Y C_{i, t} * \\
& d C A P_{i, t}+v_{i, t}
\end{aligned}
$$




\section{Results and Discussion}

\subsection{Descriptive Analysis}

Table 2 shows the descriptive statistics of research variables. Banks generally slightly increase their capital relative to assets, which is only 0.1 percent, with a relatively very large variation of 3.41 percent. Banks in Indonesia generally have sufficient capital, which is around 11 percent. Nevertheless, there is one bank with a very low capital ratio of 0.7 percent. The average ratio of risk-weighted assets to capital (RISK) during the study period was 56.96 percent with relatively small variations as reflected in the standard deviation of 14.00 percent. The average value of these risk assets indicates that during the research period commercial banks in Indonesia were not too expansive in lending. In terms of risk changes, commercial banks in Indonesia generally slightly increase the risk level as seen from the average d(RISK) of 0.9 percent with standard deviation of 9.23 percent and the lowest value range is -33.29 percent and the highest value 34.57 percent. This means that even though changes in credit risk are on average small, there is a considerable variation in risk changes among banks during the study period.

Table 2

Descriptive Statistics of Variables

\begin{tabular}{|c|c|c|c|c|c|c|c|c|c|}
\hline Variable & CAP & $\mathrm{d}(\mathrm{CAP})$ & RISK & d(RISK) & $\begin{array}{c}\text { SIZE } \\
\text { (billion) }\end{array}$ & PROF & ALL & LIQ & BUF \\
\hline Mean & 0.115 & 0.002 & 0.570 & 0.009 & 3,320 & 0.023 & 0.017 & 0.381 & 0.113 \\
\hline Median & 0.103 & 0.001 & 0.568 & 0.008 & 3,245 & 0.020 & 0.014 & 0.344 & 0.093 \\
\hline Maximum & 0.512 & 0.370 & 0.883 & 0.346 & 176,183 & 0.092 & 0.079 & 0.810 & 0.975 \\
\hline Minimum & 0.007 & -0.214 & 0.197 & -0.333 & 105 & -0.079 & 0.000 & 0.076 & -0.090 \\
\hline Std. Dev. & 0.049 & 0.034 & 0.140 & 0.092 & 6 & 0.019 & 0.011 & 0.149 & 0.082 \\
\hline
\end{tabular}

The asset size of the Indonesian banks shows very high variations. This information provides an overview of a very big gap of assets among banks in Indonesia. The ability of commercial banks to generate profits (PROF) which is measured using return on assets is relatively good, namely 2.27 percent. The PROF value is above that set by Bank Indonesia which amounted to 1.25 percent (Indonesia, 2004). The quality of commercial banks' loan, as measured by allowance for loan losses (ALL), is quite good because on average only 1.67 percent of productive assets channeled by banks are problematic. The ratio of these troubled assets is far below the Bank Indonesia regulation which stipulates a maximum of 5 percent (Indonesia, 2004). Indonesian commercial banks are also conservative in their fund placements, as can be seen from a relatively high ratio of liquid assets of 38.11 percent. This means that Indonesian commercial banks place much of their funds in liquid assets that are easily liquidated and have a level of risk.

\subsection{Bank Capital Adjustment}

Before testing the hypothesis and discussion for the $d C A P$ equation, the selection of the most appropriate analysis method is done by comparing Fixed Effect (FE) and Random Effect (RE) methods. Table 3 shows that of the two approaches, the FE is the best model in terms of its ability to explain variations in capital adjustments. The conclusion is also supported by the results of the Hausman test for Fixed/Random Effect testing.

Table 3

The Results of Capital Adjustments (dCAP)

\begin{tabular}{|c|c|c|c|c|c|}
\hline \multirow[t]{2}{*}{ Variable } & \multirow{2}{*}{$\begin{array}{c}\text { Expected } \\
\text { Sign }\end{array}$} & \multicolumn{2}{|c|}{$\mathrm{FE}$} & \multicolumn{2}{|c|}{$\mathrm{RE}$} \\
\hline & & Coef. & t-Stat. & Coef. & t-Stat. \\
\hline Constant & & 0.109 & 6.221 & 0.067 & 10,599 \\
\hline dRISK & + & 0.041 & $2.555^{*}$ & 0.091 & $5,638^{*}$ \\
\hline SIZE & - & -0.002 & $-1.900^{*}$ & -0.001 & $-1,343$ \\
\hline PROF & + & 0.028 & 0.473 & -0.027 & $-0,819$ \\
\hline LIQ & - & -0.105 & $-14.286^{*}$ & -0.086 & $-17,853^{*}$ \\
\hline $\mathrm{CAP}_{\mathrm{t}-1}$ & - & -0.774 & $-35.968 *$ & -0.626 & $-35,407 *$ \\
\hline BUF*dRISK & - & -0.162 & $-1.791 *$ & -0.283 & $-3,585^{*}$ \\
\hline CYC*Risk & - & -0.432 & $-3.492 *$ & -0.380 & $-3,386^{*}$ \\
\hline R-Square & & & & & \\
\hline Adj. R-Square & & & & & \\
\hline F-statistic & & & & & \\
\hline Prob. (F-stat) & & & & & \\
\hline \multicolumn{6}{|l|}{ Hausman Test } \\
\hline - Chi-Sq. Statistic & & 15.767 & & & \\
\hline - Prob. & & 0.039 & & & \\
\hline
\end{tabular}


Although FE is better than RE in explaining bank capital adjustments, FE still has problems related to heteroscedasticity and autocorrelation (Gujarati \& Porter, 2009). Therefore, we re-estimate FE using White's robust standard errors as presented in Table 4. It shows that there is no significant difference between the estimation results of the standard FE and the re-estimation results based on White's robust standard errors, both with the White cross-section and the White period. This means that the FE model is statistically robust. The result proves that the higher the change in risk, the higher the change in bank capital. This may prove that the main function of bank capital as a risk absorber. The greater the risk taken by the bank, the greater the capital that must be prepared by the bank (Altunbaş et al., 2001; Cannata \& Quagliariello, 2006; Ha, 2020; Rime, 2001; Rowe et al., 2004). This study uses changes in the ratio of core capital (Tier 1) to risk weighted assets (RWA) as the proxy for capital adjustment. Thus, it may indicate that Indonesia commercial banks rely on core capital as the main support for risk taking. It is in line with the expectation of the Basel (2011) and Indonesia (2013) which requires that the main sources of bank capital in absorbing risk is the core capital. Strengthening the quality of bank capital through core capital is expected to make banks more resistant to crisis shocks.

\section{Table 4}

The Results of Capital Adjustments Based on FE with Robust Standard Error

\begin{tabular}{|c|c|c|c|c|}
\hline \multirow[t]{2}{*}{ Variable } & \multicolumn{2}{|c|}{ FE-White Cross-Section } & \multicolumn{2}{|c|}{ FE-White Period } \\
\hline & Coef. & t-Stat. & Coef. & t-Stat. \\
\hline Constant & 0.109 & 5.973 & 0.109 & 6.025 \\
\hline dRISK & 0.041 & $2.367^{*}$ & 0.041 & $2.435^{*}$ \\
\hline SIZE & -0.002 & $-1.871^{*}$ & -0.002 & $-1.790^{*}$ \\
\hline PROF & 0.028 & 0.463 & 0.028 & 0.465 \\
\hline LIQ & -0.105 & $-13.297^{*}$ & -0.105 & $-12.922 *$ \\
\hline $\mathrm{CAP}_{\mathrm{t}-1}$ & -0.774 & $-32.764 *$ & -0.774 & $-30.752 *$ \\
\hline BUF*dRISK & -0.162 & $-1.782 *$ & -0.162 & $-1.781 *$ \\
\hline CYC*dRISK & -0.432 & $-2.994 *$ & -0.432 & $-2.924 *$ \\
\hline
\end{tabular}

* Significant at 5\%

The results of this study show a negative influence of total bank assets on the level of bank credit risk taking. Large banks will have a lower capital ratio that of small banks. This support the argument that large banks tend to have better access to funding sources compared to small banks (Cannata \& Quagliariello, 2006; Ghosh, 2014; Shim, 2013), get more protection from the government because large bank failures can have a systemic impact or too big to fail hypothesis (Beccalli et al., 2015; Jokipii \& Milne, 2011), and large banks have the advantage of being able to adopt a more sophisticated risk-based capital approach that tends to result in lower capital requirements (Hakenes \& Schnabel, 2011). The results of this study are also shows that the level of bank liquidity reduces the additional capital that banks must make (Altunbaş et al., 2001; Jokipii \& Milne, 2011). Besides being determined by capital, a bank's ability to absorb risk is influenced by level of liquid assets owned. The greater the liquid assets owned by the bank, the easier it is for banks to sell these assets to meet funding needs so that less capital is needed. The results of this study prove that the level of liquidity decreases the capital that must be added by the bank. This finding suggests that liquidity is a substitution of capital (Dietrich \& James, 1983). The bank's decision to increase its capital is also strongly influenced by the ratio of capital held in the previous period. Bank management can expand credit or other risky investments by using large amounts of capital that have been accumulated in the previous period without having to add new capital. Bank management realizes that the excess equity capital is expensive (Freixas \& Rochet, 2008), so that bank management chooses to optimize the utilization of available capital. Bank management does not increase capital when they know that the capital owned is high enough and still able to support potential risks posed by the expansion. Thus, the higher the capital that has been owned in the previous period, the smaller the additional capital that will be carried out by the banks in the following period.

\subsection{Bank Risk Adjustment}

Table 5 presents the test results for bank risk adjustment and shows that FE approach is the best model in terms of its ability to explain variations in capital adjustments. This conclusion is also supported by the results of the Hausman test for Fixed/Random Effect testing. Considering the potential weaknesses of the standard FE model, we estimate the risk adjustment equation using White's robust standard errors. Table 6 shows that there is no significant difference between the results of the standard FE and those of the FE White robust standard errors. The test results show that an increase in capital causes banks to take on more risk. Increased risk taking due to additional equity capital is rational for banks as a profit-oriented institution. Bank management is demanded to be able to cover the cost of capital equity banks which are relatively higher compared to the cost of third party funds such as demand deposits, savings, and deposits and debt (Freixas \& Rochet, 2008). In order to cover these more expensive costs, bank management must place their funds on more productive assets, those are assets that offer higher expected returns, albeit with higher risks (Kim \& Santomero, 1988; Koehn \& Santomero, 1980). Components of bank assets that generally provide higher expected returns are loans (Milne \& Whalley, 2001). The results of this study support portfolio theory in banking which states that the direct impact of an increase in capital is an increase in the level of bank risk (Hart \& Jaffee, 1974; Pyle, 1971). From the perspective of portfolio theory, bank investment in higher risk assets depends on the expected level of return on the 
investment. The greater the returns from lending relative to the returns of risk-free assets, the greater the proportion of bank funds placed on these higher-risk assets.

Table 5

The Results of Risk Adjustments (dRISK)

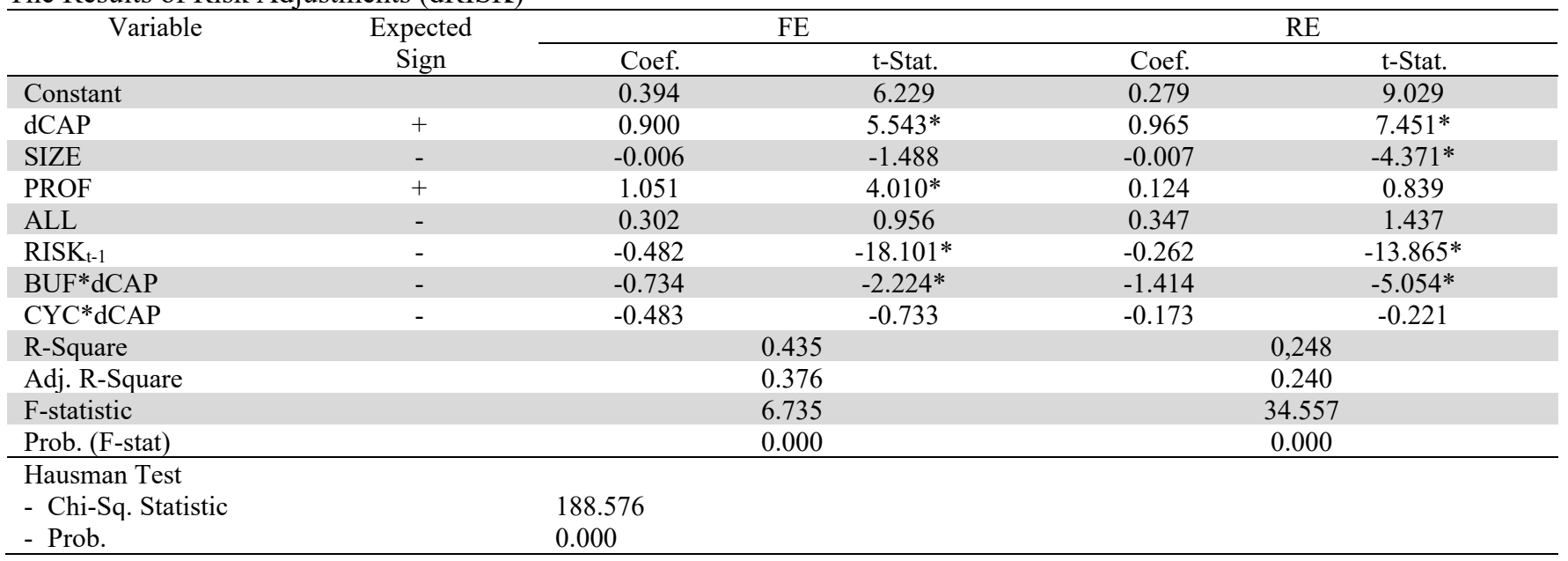

* Significant at 5\%

Table 6

The Results of Risk Adjustments Based on FE with Robust Standard Error

\begin{tabular}{lcccc}
\hline & Variable & \multicolumn{2}{c}{ FE-White Cross-Section } & \multicolumn{2}{c}{ FE-White Period } \\
\cline { 2 - 5 } & Coef. & t-Stat. & Coef. & t-Stat. \\
\hline Constant & 0.394 & 5.292 & 0.394 & 6.337 \\
dRISK & 0.900 & $5.445^{*}$ & 0.900 & $4.948^{*}$ \\
SIZE & -0.006 & -1.524 & -0.006 & -1.429 \\
PROF & 1.051 & $3.212^{*}$ & 1.051 & $3.921^{*}$ \\
LIQ & 0.302 & 0.876 & 0.302 & 0.907 \\
CAPt-1 & -0.482 & $-17.821^{*}$ & -0.482 & $-16.212^{*}$ \\
BUF*dRISK $_{\text {CYC*dRISK }}$ & -0.734 & $-2.121^{*}$ & -0.734 & $-1.974^{*}$ \\
\hline
\end{tabular}

* Significant at 5\%

The results also show that profitability, measured using return on assets, has a significant positive effect on changes in credit risk. When a bank makes asset allocation decisions, it is faced with solving the trade-off problem between the risk and the expected level of return (Boyd \& De Nicolo, 2005). If the bank's decision is to increase the level of profit, the bank must be willing to bear a higher risk (Kim \& Santomero, 1988; Koehn \& Santomero, 1980). Channeling funds on credit offers a higher potential for default (risk) compared to placements in central bank or government securities (García-Herrero et al., 2009; Jeitschko \& Jeung, 2007). This higher risk, however, is also accompanied by a higher expected profit. The results also show that the previous year's risk level has a negative effect on the risk adjustments. When the risk in the previous period is too high, bank management will try to reduce or at least not increase the level of risk in the following period. An incremental of the risk level beyond the tolerable could pose compliance risks in the form of sanctions from the banking supervisory authority as well as cause banks to not be able to cover the potential for large losses that arise because of inadequate available capital. Therefore, bank management continues to strive to ensure that the level of bank risk is not that high over time by restraining or even reducing credit expansion (Cannata \& Quagliariello, 2006; Godlewski, 2005). Conversely, banks with a relatively low accumulation of risk levels in the past have better leeway in meeting the regulatory capital so that they have more space to take greater risks.

\subsection{Moderating Role of Capital Buffer}

Table 3 and Table 4 show that the interaction between capital buffer and changes in risk negatively affects changes in capital. Banks with high capital buffers add less capital than banks with low capital buffers when they increase risk. They have a plenty of capital so that they do not need to increase capital much when making credit expansion because the existing capital is still able to cover potential losses that may arise from the credit expansion. In contrast, banks with low capital buffers are forced to increase more capital increasing their risk taking. These banks face threats from banking supervisory authorities in the form of 
temporary suspension of activity or, worst of all, bank closure if capital falls below the minimum requirement. These sanctions force banks to increase their capital more significantly (Ediz et al., 1998; Heid et al., 2004). Banks with relatively low capital buffers may also lose market share that switch to well-capitalized banks because the public views they are unhealthy banks. This potential loss of market share could force low-capitalized banks to increase more capital (Jokipii \& Milne, 2011), adjust their capital faster than that of well-capitalized banks when adding risk (Abbas \& Masood, 2020; Jeitschko \& Jeung, 2007), and, in an extreme case, increase their capital and reduce the risks simultaneously (Jokipii \& Milne, 2011).

Table 5 and Table 6 show that the interaction between capital buffer and capital change negatively affects risk change. It means that the level of capital buffers weaken the effect of capital adjustments on risk adjustments (Calomiris \& Kahn, 1991; Diamond \& Rajan, 2000). Banks with low capital buffers increase their risk more significantly, generally through lending, than that of well-capitalized banks when they add more capital. The greater credit expansion carried out by low-capitalized banks may result in a high risk of credit default. The negative moderating of capital buffers may also suggest that banks with low or even negative capital levels speculate to rise up from their downturn by exploiting depositors and deposit insurance institutions by taking higher risks than the available capital (Holmstrom \& Tirole, 1997; Miles, 1995; Milne, 2006; Sharpe, 1990). When the increased risk through credit expansion is successful, the difference between the interest incomes received by the bank exceeds the interest expenses that must be paid by the bank to the depositor, then the excess goes to the bank's owner. Conversely, when this credit expansion lead to problem loans, then part of the loss will be borne by the deposit insurance agency. In the case of Indonesia, the Indonesian deposit insurance institution, guarantees depositor's funds up to IDR 2 billion per account in one bank. LPS annual report shows that 90 percent of public accounts and 55 percent of public funds in Indonesian banks are guaranteed (Simpanan, 2018).

\subsection{Moderating Role of Business Cycle}

Table 3 and Table 4 also reveal that the interaction between business cycle and changes in risk negatively affects changes in capital. This implies that banks add more capital during economic conditions deteriorate compared to that of during good economic conditions. When the economy is growing rapidly, debtors do not face serious problems in running their business so they are able to repay their loans well. With a low default rate, banks are not worried about the risks arising from credit expansion. Consequently, banks do not need to increase capital when increasing the risk. When the business cycle goes down, however, banks' capital buffers cannot absorb the soaring credit risks. Furthermore, banks are forced to increase their capital more significantly and even at the same time reduce their lending to meet the minimum capital requirement. During an economic crisis that causes high non-performing loans, banks increase their capital significantly to cover the increasing risks (Ovi et al., 2020; Shim, 2013; Stolz \& Wedow, 2011). This finding is also in line with the disaster myopia hypothesis which states that when the economic conditions are good the bank believes that these conditions will continue in the future (Guttentag \& Herring, 1984). This belief encourages banks to expand credit and relax credit standards, without accumulating adequately capital (Borio et al., 2001). When the economic crisis occurs and the risk of credit failure soars, the banks do not have enough capital to bear the loss. To prevent from being liquidated, the bank adds a significant amount of capital and drastically reduces their risks (García-Suaza et al., 2012). This study also supports the herd behavior hypothesis (Rajan, 1994). Bank management trapped into credit policy that is not the best one because other banks do the same thing. Although the bank's risk is high and its performance is poor, bank management does not need to feel "embarrassed" because other banks are in similar condition. This causes banks to reduce credit quality which can further increase the credit risk faced. Last, Table 5 and Table 6 indicate that the interaction between business cycle and changes in capital does not significantly affects changes in risk. This means that the business cycle does not prove to weaken the influence of capital adjustments on risk adjustment. The results do not support business cycle theory which estimates that bank capital moves against the business cycle (Jokipii \& Milne, 2008). The results of this study may imply that risk adjustment for Indonesian commercial banks is more determined by the amount of available capital. This occurred because when submitting their business plan to the banking authorities, they are required to provide sufficient capital when planning credit expansion.

\section{Conclusion}

Based on the results of the testing and discussion, there are three main conclusions that can be drawn. First, changes in credit risk and changes in capital influence each other simultaneously in a positive direction. Second, the level of capital buffer weakens the influence of risk adjustments on capital adjustments and the effect of capital adjustments on risk adjustments. This means that banks with low capital buffer tend to take higher risks when raising capital compared to that of banks with high capital buffer. Third, the business cycle weakens the influence of risk adjustment on capital adjustments but does not weaken the effect capital adjustment on risk adjustments. During a good economic condition, banks do not accumulate adequate capital at the time of credit expansion because they consider everything will work well and there will be no significant problem loans. When a crisis occurs and non-performing loans soaring, however, banks significantly increase their capital and simultaneously reduce their credit expansion to keep the capital ratio from falling below the minimum capital requirement. 
There are some practical implications of this study. The Financial Services Authority must strengthen bank supervision despite in good economic conditions and ensuring that an increase in bank risk, mainly through credit expansion, must be accompanied by an adequate increase in capital. Good economic conditions could encourage banks to carry out excessive credit expansion which, if without prudential principles, could cause many banks to go bankrupt (credit crunch). The Financial Services Authority also has to pay more attention to banks with a low capital buffer because this category of banks speculates more by increasing credit risk without accumulating adequate capital. Last, the Deposit Insurance Corporation needs to think about implementing a risk-based guarantee premium. With a fixed premium currently applied, banks may have incentives to take high risks because they do not have to pay a higher premium. With this scheme of premium, the bank's loss is only as much as the premium paid but the potential profit of the bank can be unlimited.

\section{Acknowledgement}

We would like to thank the Ministry of Research Technology and Higher Education Republic of Indonesia which has provided fundamental research grants for this study.

\section{References}

Abbas, F. \& Masood, O. (2020). How do large commercial banks adjust capital ratios: empirical evidence from the US? Economic Research-Ekonomska Istraživanja, 33(1), 1849-1866.

Aggarwal, R. \& Jacques, K. T. (1998). Assessing the impact of prompt corrective action on bank capital and risk. Economic Policy Review, 4(3), 23-32.

Altman, E. I., Brady, B., Resti, A., \& Sironi, A. (2005). The link between default and recovery rates: Theory, empirical evidence, and implications. The Journal of Business, 78(6), 2203-2228.

Altunbaş, Y., Carbo, S., \& Gardener, E. P. (2001). The impact of CAR on bank capital augmentation in Spain. In Bank Strategies and Challenges in the New Europe (pp. 213-231), Springer.

Asea, P. K. \& Blomberg, B. (1998. Lending cycles. Journal of Econometrics, 83(1), 89-128.

Ayuso, J., Pérez, D., \& Saurina, J. (2004). Are capital buffers pro-cyclical?: Evidence from Spanish panel data. Journal of Financial Intermediation, 13(2), 249-264.

Basel. (2011). Basel III: A Global Regulatory Framework for more Resilient Banks and Banking System. Basel.

Basheer, M., Ahmad, A., \& Hassan, S. (2019). Impact of economic and financial factors on tax revenue: Evidence from the Middle East countries. Accounting, 5(2), 53-60.

Beccalli, E., Anolli, M., \& Borello, G. (2015). Are European banks too big? Evidence on economies of scale. Journal of Banking \& Finance, 58: 232-246.

Bhagat, S., Bolton, B., \& Lu, J. (2015). Size, leverage, and risk-taking of financial institutions. Journal of banking \& finance, 59, 520-537.

Borio, C., Furfine, C., \& Lowe, P. (2001). Procyclicality of the financial system and financial stability: issues and policy options. BIS papers, 1, 1-57.

Boyd, J. H. \& De Nicolo, G. (2005). The theory of bank risk taking and competition revisited. The Journal of Finance, 60(3), 1329-1343.

Calomiris, C. W. \& Kahn, C. M. (1991). The role of demandable debt in structuring optimal banking arrangements. The American Economic Review: 497-513.

Cannata, F. \& Quagliariello, M. (2006). Capital and risk in Italian banks: A simultaneous equation approach. Journal of Banking Regulation, 7(3-4), 283-297.

Demsetz, R. S. \& Strahan, P. E. (1997). Diversification, size, and risk at bank holding companies. Journal of Money, Credit, and Banking, 29(3), 300-313.

Diamond, D. W. \& Rajan, R. G. (2000). A theory of bank capital. The Journal of Finance, 55(6), 2431-2465.

Duran, M. A. \& Lozano-Vivas, A. (2015). Moral hazard and the financial structure of banks. Journal of International Financial Markets, Institutions and Money, 34, 28-40.

Ediz, T., Michael, I., \& Perraudin, W. (1998). The impact of capital requirements on UK bank behaviour. Economic Policy Review, 4(3), 15-22.

Freixas, X. \& Rochet, J.-C. (2008). Microeconomics of banking. MIT press.

García-Herrero, A., Gavilá, S., \& Santabárbara, D. (2009). What explains the low profitability of Chinese banks? Journal of Banking \& Finance, 33(11), 2080-2092.

García-Suaza, A. F., Gómez-González, J. E., Pabón, A. M., \& Tenjo-Galarza, F. (2012). The cyclical behavior of bank capital buffers in an emerging economy: Size does matter. Economic Modelling, 29(5), 1612-1617.

Ghosh, S. (2014). Risk, capital and financial crisis: Evidence for GCC banks. Borsa Istanbul Review, 14(3), $145-157$.

Godlewski, C. J. (2005). Bank capital and credit risk taking in emerging market economies. Journal of Banking Regulation, $6(2), 128-145$. 
Gujarati, D. N. \& Porter, D. (2009). Basic Econometrics Mc Graw-Hill International Edition.

Guttentag, J. \& Herring, R. (1984). Credit rationing and financial disorder. The Journal of Finance, 39(5), 1359-1382.

Ha, V. (2020). Does bank capital affect profitability and risk in Vietnam? Accounting, 6(3), 273-278.

Hadad, M. D., Satrio, W., Handoko, S., Yuniar, M., \& Noviati, N. (2003). Kajian Mengenai Efektivitas Kebijakan Obligasi Rekap.

Hair, J. F., Black, W. C., Babin, B. J., \& Anderson, R. E. (2014). Multivariate data analysis. 7 ed. Essex: Pearson Education Limited.

Hakenes, H. \& Schnabel, I. (2011). Bank size and risk-taking under Basel II. Journal of banking \& finance, 35(6), 1436-1449.

Hart, O. D. \& Jaffee, D. M. (1974). On the application of portfolio theory to depository financial intermediaries. The Review of Economic Studies, 41(1), 129-147.

Heid, F., Porath, D., \& Stolz, S. (2004). Does capital regulation matter for bank behaviour? Evidence for German savings banks. In, Discussion Papers - Series 2: Banking and Financial Supervision: Deutsche Bundesbank.

Holmstrom, B., \& Tirole, J. (1997). Financial intermediation, loanable funds, and the real sector. The Quarterly Journal of Economics, 112(3), 663-691..

Indonesia, B. (2004). Surat Edaran Bank Indonesia No. 6/23/DPNP tentang Sistem Penilaian Tingkat Kesehatan Bank Umum. Jakarta: Bank Indonesia

Indonesia, B. (2013). Peraturan Bank Indonesia No. (15/12/PBI/2013 Tentang Kewajiban Penyediaan Modal Minimum Bank Umum. Jakarta: Bank Indonesia

Jacques, K. \& Nigro, P. (1997). Risk-based capital, portfolio risk, and bank capital: A simultaneous equations approach. Journal of Economics and business, 49(6), 533-547.

Jeitschko, T. D. \& Jeung, S. D. (2007). Do well-capitalised banks take more risk? Evidence from the Korean banking system. Journal of Banking Regulation, 8(4), 291-315.

Jokipii, T. \& Milne, A. (2008). The cyclical behaviour of European bank capital buffers. Journal of Banking \& Finance, 32(8), 1440-1451.

Jokipii, T. \& Milne, A. (2011). Bank capital buffer and risk adjustment decisions. Journal of Financial Stability, 7(3), 165-178.

Kim, D. \& Santomero, A. M. (1988). Risk in banking and capital regulation. The Journal of Finance, 43(5), 1219-1233.

Koehn, M. \& Santomero, A. M. (1980). Regulation of bank capital and portfolio risk. The Journal of Finance, 35(5), 12351244.

Marcucci, J. \& Quagliariello, M. (2008). Is bank portfolio riskiness procyclical?: Evidence from Italy using a vector autoregression. Journal of International Financial Markets, Institutions and Money, 18(1), 46-63.

Marcus, A. J. (1984). Deregulation and bank financial policy. Journal of banking \& finance, 8(4), 557-565.

Miles, D. (1995). Optimal regulation of deposit taking financial intermediaries. European Economic Review, 39(7), 1365-1384.

Milne, A. (2006). Optimal regulation of deposit taking financial intermediaries: A correction. European Economic Review, 50(2), 509-516.

Milne, A. \& Whalley, A. E. (2001). Bank capital regulation and incentives for risk-taking. Cass Business School Research Paper.

Nachane, D. \& Ghosh, S. (2001). Risk-Based Standards, Portfolio Risk and Bank Capital: An Econometric Study. Economic and Political Weekly, 36(10), 871-876.

Ovi, N., Bose, S., Gunasekarage, A., \& Shams, S. (2020). Do the business cycle and revenue diversification matter for banks' capital buffer and credit risk: Evidence from ASEAN banks. Journal of Contemporary Accounting \& Economics, 100186.

Porteous, B. \& Tapadar, P. (2005). Economic capital and financial risk management for financial services firms and conglomerates. Palgrave Macmillan.

Pyle, D. H. (1971). On the theory of financial intermediation. The Journal of Finance, 26(3), 737-747.

Quagliariello, M. (2007). Banks' riskiness over the business cycle: a panel analysis on Italian intermediaries. Applied Financial Economics, 17(2), 119-138.

Rajan, R. G. (1994). Why bank credit policies fluctuate: A theory and some evidence. the Quarterly Journal of economics, 109(2), 399-441.

Raz, A. F. (2018). Risk and capital in Indonesian large banks. Journal of Financial Economic Policy, 10(1), 165-184.

Rime, B. (2001). Capital requirements and bank behaviour: Empirical evidence for Switzerland. Journal of banking \& finance, 25(4), 789-805.

Rowe, D., Jovic, D., \& Reeves, R. (2004). Basel II and economic capital. US Banker, April: 28-62.

Setyawati, I., Widyastuti, T., Suryati, A., \& Hartani, N. (2019). Intellectual capital performance of Islamic banks in Indonesia: Towards competitive advantages. Management Science Letters, 9(12), 1999-2008.

Sharpe, S. A. (1990). Asymmetric information, bank lending, and implicit contracts: A stylized model of customer relationships. The Journal of Finance, 45(4), 1069-1087.

Shim, J. (2013). Bank capital buffer and portfolio risk: The influence of business cycle and revenue diversification. Journal of banking \& finance, 37(3), 761-772.

Shrieves, R. E. \& Dahl, D. (1992). The relationship between risk and capital in commercial banks. Journal of banking \& finance, 16(2), 439-457. 
Siddika, A. \& Haron, R. (2019). Capital regulation and ownership structure on bank risk. Journal of Financial Regulation and Compliance, 28(1), 39-56.

Simpanan, L. P. (2018). Annual Report 2011. Jakarta: Lembaga Penjamin Simpanan

Sinkey, J. F. \& Greenawalt, M. B. (1991). Loan-loss experience and risk-taking behavior at large commercial banks. Journal of Financial Services Research, 5(1), 43-59.

Stolz, S. \& Wedow, M. (2011). Banks' regulatory capital buffer and the business cycle: Evidence for Germany. Journal of Financial Stability, 7(2), 98-110.

Tan, Y., Floros, C., \& Anchor, J. (2017). The profitability of Chinese banks: impacts of risk, competition and efficiency. Review of Accounting and Finance.

Van Roy, P. (2008). Capital requirements and bank behavior in the early 1990s: Cross country evidence. International Journal of Central Banking, 4(3), 29-60.

Yu, H. C. (2000). Banks' Capital Structure and the Liquid Asset-Policy Implication of Taiwan. Pacific Economic Review, 5(1), 109-114.

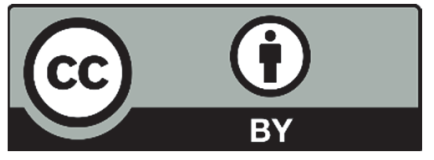

(C) 2020 by the authors; licensee Growing Science, Canada. This is an open access article distributed under the terms and conditions of the Creative Commons Attribution (CC-BY) license (http://creativecommons.org/licenses/by/4.0/). 